\title{
Growth and Yield Response of Melon to Different Time Application of Goat Manure and Dose of Potassium
}

\author{
Merakati Handajaningsih, Marwanto, Tri Armitasari, Entang Inoriah, Hesti Pujiwati \\ Department of Crop Production, Faculty of Agriculture, University of Bengkulu \\ WR Supratman St, Kandang Limun, Bengkulu 38371, Indonesia
}

\author{
ARTICLE INFO \\ Keywords: \\ Melon, goat manure, \\ potassium, growth, yield \\ Article history: \\ Received: March 24, 2018 \\ Accepted: June 26, 2018 \\ *Corresponding author: \\ E-mail: merakati@unib.ac.id
}

\begin{abstract}
Goat manure contains high potassium, thus it is expected to reduce the usage of synthetic potassium fertilizer. Incubation of goat manure is needed prior to planting since the nutrients are slow release. The objective of the experiment was to find the best time application and dose of potassium on growth and yield of melon. Container experiment using polybags was set in Completely Randomized Design. Goat manure were incorporated into soil at the time of transplanting (0 DBT), 5 days before transplanting (5 DBT), and $10 \mathrm{DBT}$. The dose of potassium was consisted of $0 \mathrm{~kg} / \mathrm{ha}, 200 \mathrm{~kg} / \mathrm{ha}$ and $400 \mathrm{~kg} / \mathrm{ha}$. The treatments were repeated 3 times, each of which consisted of 4 plants. Growth and yield of plants showed no response to the interaction between the two factors of treatment. Single treatment effect of time applicaton of goat manure 10 DBT affected leaf area $\left(1619.51 \mathrm{~cm}^{2}\right)$, fruit weight $(872 \mathrm{~g})$, fruit diameter $(16.19 \mathrm{~cm})$ and the thickness of edible fruit part $(2.61 \mathrm{~cm})$. The dose of potassium $400 \mathrm{~kg} / \mathrm{ha}$ increased fruit sweetness to $8.2 \%$ Brix. .
\end{abstract}

\section{INTRODUCTION}

The practice of using organic matter in cultivation of most horticultural crops including melon (Cucumis melo L.) is inevitable, and more pronounce in its relation with sustainable agriculture system in the form of combination between inorganic fertilizer and organic fertilizer. This such kind of practice on the farm is one way to reduce the impact of declining soil productivity due to conventional agricultural systems in the form of high inputs of inorganic fertilizers. Inputs of organic materials can improve soil structure which during some recent decades has been detected to decrease more and more due to excessive chemical fertilizer .

Organic matter is dead parts of plant or animal that constantly undergoes changes in shape and structure because of its influenced by biological, physical and chemical factors. This decomposition process will end as humus which can enrich microorganisms, produces nutrients and useful materials for plants. Organic matter increases soil aggregates so can increase water infiltration. One source of organic matter is goat manure. Manure can be used as a better soil enhancer than synthetic enhancers, although in general manure has low macro nutrients such as $\mathrm{N}, \mathrm{P}, \mathrm{K}$ but it contains sufficient amount of micro nutrients that are indispensable for growth plant. Goat manure needs longer to effect plant growth and yield because goat manure has a unique granule textures, rather difficult to break, and the water content is relatively lower compared to cow manure and chicken manure. This suggests that goat manure has an effect for a long period of time, the plant nutrients gradually become available to crops. Goat manure considered having higher persentage in potassium nutrient when compared with other manures. It contains potassium $2.88 \%$ which is higher than $\mathrm{K}$ element in cow manure $(0.69 \%)$ and chicken manure $(1.45 \%)$. Some other essential nutrients in goat manure are Nitrogen $2.77 \%$, and $1.78 \%$.

Potassium is a nutrient that has an important role in plant growth such as cell division, stomatal opening, photosynthesis, sugar translocation, protein synthesis and converting carbohydrates into fructose in fruit. Crops under nutrient deficiency show less resistance to drought, more sensitivity to disease, and reduced product quality. Some research on organic fertilizer and goat manure, found that the use of organic materials 10 tons / ha or $450 \mathrm{~g} /$ plant, affect the weight of melon fruit with an average of $2.29 \mathrm{~kg}$, and

ISSN: $1410-3354$ / e-ISSN:2615-7136

Cited this as: Handajaningsih,M., Marwanto, T.Armitasari, E. Inoriah, and H. Pujiwati. 2018. Growth and yield response of melon to different time application of goat manure and dose of potassium. Akta Agrosia 21(1):1-5. 
the diameter of melon fruit with an average of 25 , $87 \mathrm{~cm}$. In Pasaribu's research, (2014) stated that the use of manure derived from goat droppings at a dose of $3.55 \mathrm{~kg} /$ polybag is able to increase the weight of melon fruit reaches $1.36 \mathrm{~kg}$ with sugar content of 9.21 0Brix. Siswanto et al. (2010) found the use of organic materials, potassium, and dolomite can improve the sugar content in melon fruit to $13 \%$ Brix. In several studies when the application of organic materials and goat manure, it was found that the provision of goat manure at the time of planting significantly affected the growth of chilli at 14 days after planting (Silvia, 2012). Research conducted by Handajaningsih et al. (2016) revealed that the application of ameliorant 5 and $10 \mathrm{dbt}$ gave better yield on sweet corn compared with ameliorant applied at planting date. Research on the time of application of manure derived from goat manure and different doses of $\mathrm{KCl}$ in melon plants has not been done in Bengkulu, so it is expected that this research can determine the time of application of goat manure and the $\mathrm{KCl}$ fertilizer dosage on growth and yield of melon. Masnag (2003) showed improvement of nutrient efficiency can be done with some techniques those are the right time, right dose, right kind, proper way of fertilizer needed by plant. This research aimed to evaluate the response of melon to different time application of goat manure and different dose of potassium fertilizer.

\section{MATERIALS AND METHOD}

This research has been conducted from July to September 2015. The location of the field research was in Kandang Limun sub-district of Muara Bangkahulu, Bengkulu city, the elevation of the area was $25 \mathrm{~m}$ above sea level. Type of soil that is used as a medium of experiment was ultisol soil that has not been used for agriculture cultivation. The experimental design used in this research was Completely Randomized Design. The first factor was the time of application of goat manure consisting of $\mathrm{K} 0=0$ day before planting (DBP), K1 $=5 \mathrm{DBP}, \mathrm{K} 2=$ 10 DBP. Second factor was $\mathrm{KCl}$ fertilizer dosage consisting of $\mathrm{P} 0=0 \mathrm{~kg} / \mathrm{ha}, \mathrm{P} 1=200 \mathrm{~kg} / \mathrm{ha}, \mathrm{P} 2=$ $400 \mathrm{~kg} / \mathrm{ha}$. Each treatment was repeated 3 times, each unit of which were 6 plants.

The study was started by preparing the material, plant production facilities and land for the implementation of the experiment. Goat manure was obtained from local goat farmer of Central Bengkulu. Planting medium used in the form of soil mix consisting of Ultisol $8 \mathrm{~kg}$ / polybag, $250 \mathrm{~g} /$ polybag dolomite, goat manure compost as much as $3.5 \mathrm{~kg} /$ polybag, and rice husk as much as $0.75 \mathrm{~kg} /$ polybag. These mix planting media was filled into the polybags, sized $40 \mathrm{~cm}$ x $50 \mathrm{~cm}$ capacity $10 \mathrm{~kg}$. Polybags were arranged in $25 \mathrm{~cm}$ in row and $50 \mathrm{~cm}$ between row.

Melon seed used as planting material was Action 434 with seed germinability $90 \%$. Media for seedlings was compost and topsoil 1: 1 ratio, filled into $12 \mathrm{~cm} \mathrm{X}$ $8 \mathrm{~cm}$ polybags. Melon seeds were soaked for 1 hour into the water, then the seeds planted in a depth of 2-3 $\mathrm{cm}$. Carbofuran was included to avoid insect.
Irrigation was done by hand spraying twice a day in the morning and the evening. Three weeks old seedlings were transplanted to the growing polybag.

Fertilizers included in this experiment were Urea with the dose of $8.3 \mathrm{~g} /$ polybag, SP-36 with a dose of $7.1 \mathrm{~g} /$ polybag, and $\mathrm{KCl}$ was given in accordance with the treatments. Multiple fertilizer 16:16:16 was given at 21 dat and 28 dat at a dose of $2.4 \mathrm{~g} /$ polybag each application. Plant watering done twice a day, in morning 06:00 to 07:00 a.m. and inthe afternoon at 16:00 to $17: 00 \mathrm{pm}$. Binding of melon stem with nylon thread is done after the plant was 25 dat when plant tendrils came out. The binding of the stems was done by tied the plant within $5 \mathrm{~cm}$ above the ground to the upper part of the plant stem (Efendi, 2014). Pruning of secondary branch was done under the 9th main stem node and above the 13th stem node. The meristem shoot on main stem was cut when at the 21 st node to stop the vegetative growth of the plant. Selection of the fruit was done by leaving one fruit in one plant which developed between the node $9-13$. Fruit wrapping was done when the young selected fruit began to develop. This was practiced to avoid pest attacks.

Some plants at age 31 dat during the experiment injured from leaf blight caused by fungus Pseudoperonospora cubensis. Control was done manually by cutting the injured leaves. Chemical control was done by using pesticide methyl triponate $1 \mathrm{~g} / \mathrm{L}$ and dehipon $2 \mathrm{~mL} / \mathrm{L}$. Fruits were harvested on 64 dat after melon fruit showiing half slip.

Variables both growth and yield included: 1 . Plant height $(\mathrm{cm})$, was measured starting from the base of the main stem to the highest main stem of the plant. Plant height measurements were performed when the plant was 64 dat. 2 . Number of leaves was calculated at 64 dat. 3.The stem diameter $(\mathrm{mm})$ was measured using a plant caliper. Measurements were performed at $30 \mathrm{~cm}$ apart from the base of the main stem consistently in each sample plant. Measurement of stem diameter was done when the plant age was 64 dat. 4. Leaf area $\left(\mathrm{cm}^{2}\right)$, measured using leaf area meter. Measurement of leaf area was done at plant age of 64 dat. 5.Weight of fresh fruit $(\mathrm{g})$ was measured using digital balance. Fresh weight measurement of fruit was done 3 days after harvested. 6. Fruit diameter $(\mathrm{cm})$ was measured by cutting the melon fruit transversely. Measurement of fruit diameter was done. 7. The thickness of the edible fruit $(\mathrm{cm})$ was measured using the ruler by cutting the melon fruit transversely on endocarp part of fruit. 8.Fruit sweetness (0Brix) was measured using handrefractometer. The data obtained from the observation were analyzed statisticaly using ANAVA. In the variables showed significantly different were performed using Polynomial Orthogonal. Growth pattern leaf area was presented in graph.

\section{RESULTS AND DISCUSSION}

Soil used for planting media in this research is Ultisol which is characterized with poor macro elements such as $\mathrm{N}, \mathrm{P}, \mathrm{K}$ and micro nutrients such as $\mathrm{Mo}, \mathrm{Ca}, \mathrm{Mg}$, and $\mathrm{S}$. The values of goat manure 
analysis showed nutrient content of $\mathrm{N} 0.53 \%, \mathrm{P} 2 \mathrm{O} 5$ $0.38 \%, \mathrm{~K} 2 \mathrm{O} 0.20 \%, \mathrm{CaO} 0.30 \%$ and $\mathrm{MgO} 0.15 \%$.

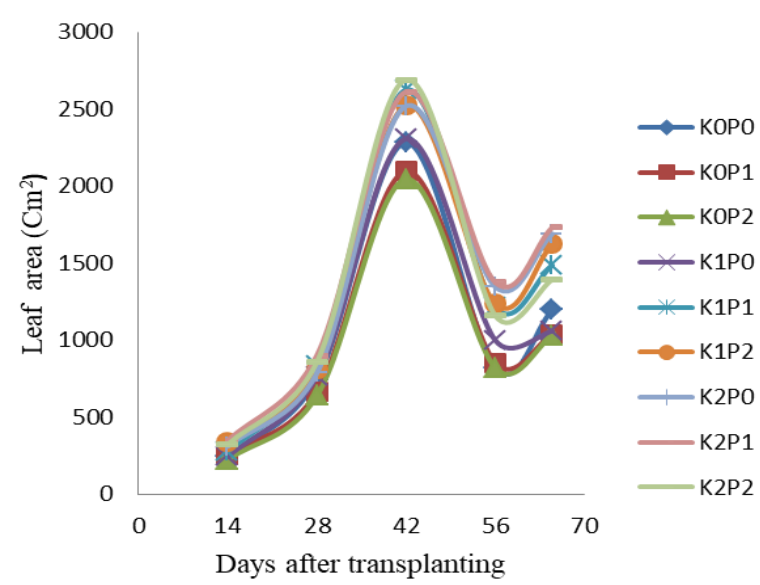

Figure 1. Growth pattern of leaf area of melon plant

The rainfall during the study ranged from 0 to 7.02 $\mathrm{mm} /$ month or almost no rain, the climatic condition that did not support the growth of melon plants. The melon plants require rainfall of $250 \mathrm{~mm} /$ month (Soedarya, 2010). Lack of water causes the growth of melon plants was not good, especially during the vegetative phase.

The result of analysis of varian showed that the time of application of goat manure significantly affect to the variables of leaf area, fruit weight, fruit flesh thickness, and fruit diameter. The dose of $\mathrm{KCl}$ showed a significant effect on the fruit sweetness level variable, but did not show any significant effect on the other variables. This might be due to excessive consumption of $\mathrm{K}$ during plant growth that deprive the absorption of $\mathrm{Ca}$ and $\mathrm{Mg}$ elements by plants. In vegetative growth excess $\mathrm{K}$ this will reduce the transport of $\mathrm{Ca}$, whereas $\mathrm{Ca}$ plays a role in plant growth. According to Soepardi (1983) characteristic of $\mathrm{K}$ in soil when excessive consumption of $\mathrm{K}$ occurs, other cation translocations may be disrupted. The study did not show the interaction between goat manure application and the dose of $\mathrm{KCl}$ fertilizer.

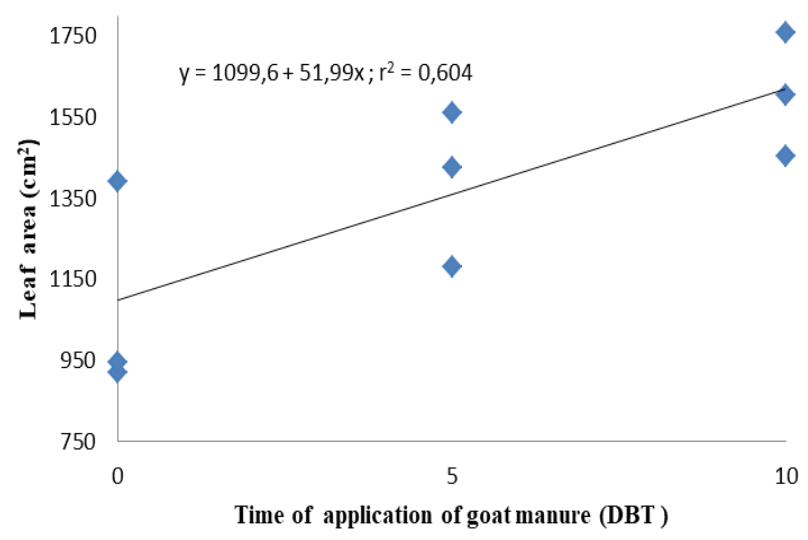

Figure 2. Leaf area of melon as affected by application time of goat manure.

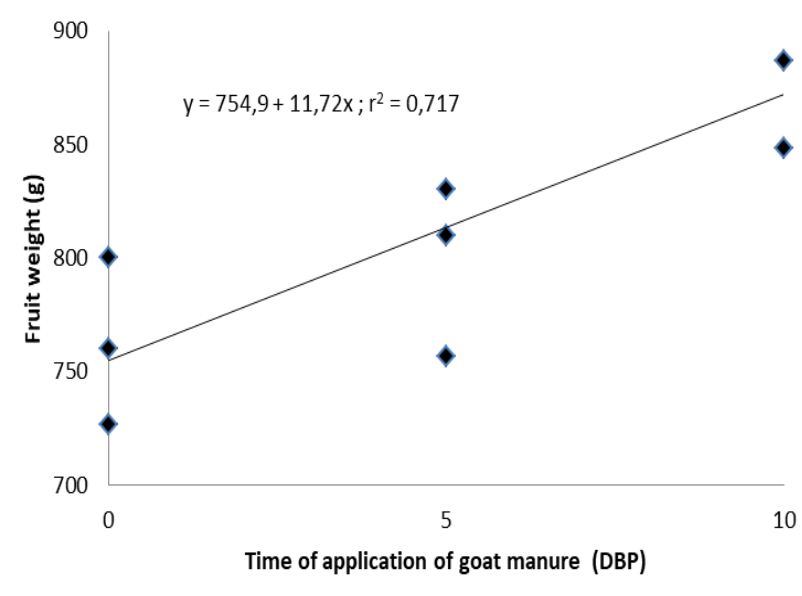

Figure 3. Fruit weight of melon as affected by time of application of goat manure

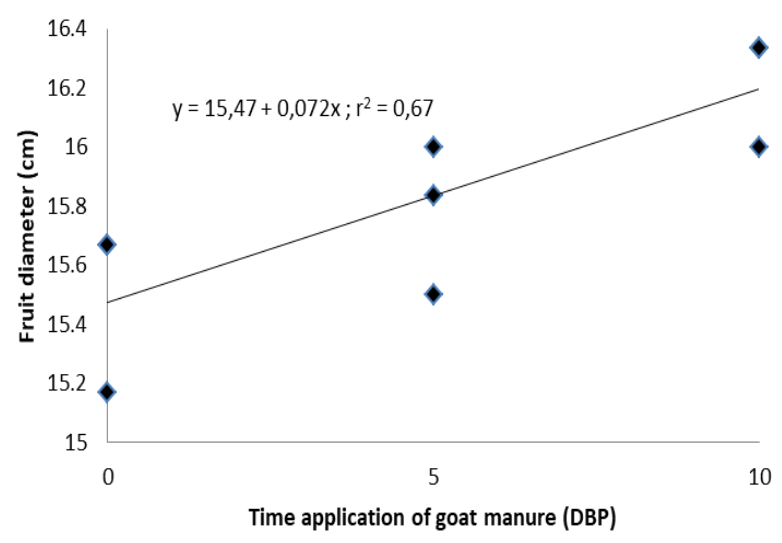

Figure 4. Fruit diameter as affected by time of application of goat manure

\section{Effect of time of application of goat manure on leaf area}

Plant growth can be observed by measuring the increase in the number and volume of cells. Measuring leaf area is important as growth indicator since leaf of melon is the main part of photoshyntetic organ. The result showed that the growth of leaf area

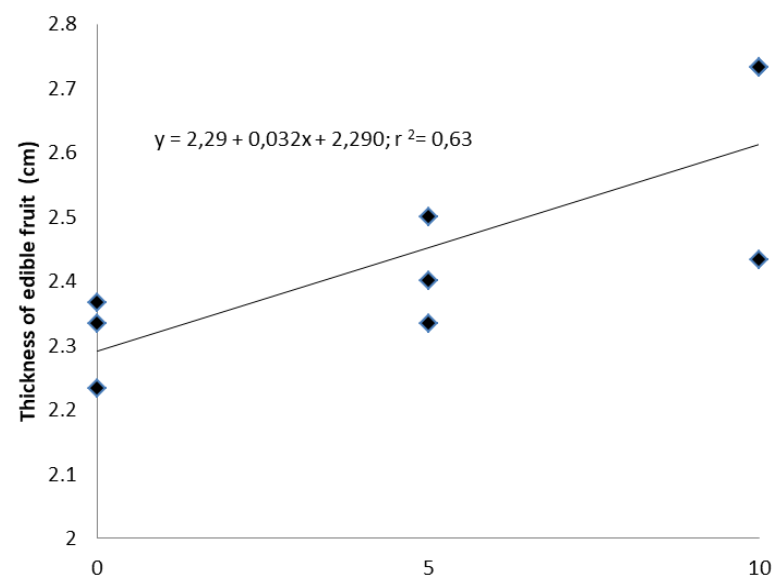

Figure 5. The thickness of the edible fruit as affected by the time of application of goat manure. 
at plant age of 1428 , and 42 dat increased normally . The $\mathrm{K} 2 \mathrm{P} 2$ treatment, the application time of goat manure of $10 \mathrm{DBT}$ and the dosage of $\mathrm{KCl} 400$ $\mathrm{kg} / \mathrm{ha}$, yielded the highest average value when compared with other treatments. However, when the plant age reached 56 days, the leaf area decreased (Figure 1), due to the loss of leaves caused by honey mildew disease.

The number of leaves affects the area of plant leaves (Gomies et al., 2012). Compost manure that is not mature perfectly can be the agent of fungal pathogens. Melon cultivar Action 434 as parental and Yacapa as its hybrid was detected on its heritance

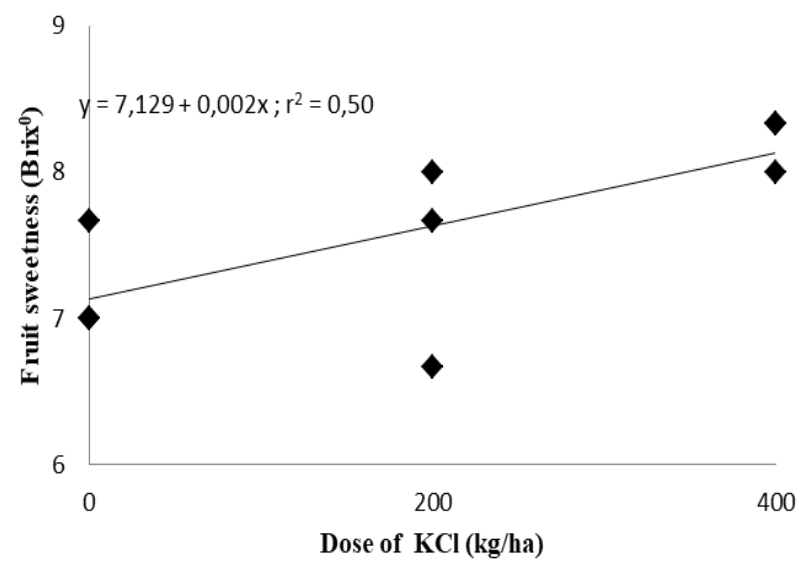

Figure 6. Effect of the dose of $\mathrm{KCl}$ fertilizer to the fruit sweetness.

to downey mildew disease (Aristya and Perwitasari., 2014). Meanwhile, Yogev (2009) mature cow manure compost mixed with orange peels, or with wheat straw, or with dried tomato significantly can suppress the Fusarium disease on melon plant caused by Fusarium oxysporum form melonis. Hock et al. (2014) proved the role of compost in suppressing wilt disease by infusing Trichoderma into the compost.

Application of goat manure from date of planting until 10 DBT was responded linierly to leaf area (Figure 2). Safuan et al., (2012) reported that applying organic matter 35 DBT had an effect on the best melon leaf area. Saputra, (2009) also stated that the application of azolla compost 21 DBT can increase the leaf area of kailan plants.

The fruit weight had positive linear response to the application time of goat manure with the equation $\mathrm{y}=7.13+0.0025 \mathrm{x}(\mathrm{r} 2=0.50)$ (Figure 3). Fruit diameter showed a positive response to application time of goat manure by forming linear curve $\mathrm{y}=$ $15.47+0.072 \times(\mathrm{r} 2=0.67)$ (Figure 4). The thickness of the fruit increases with the length of time the application of goat manure with the linear pattern $y=$ $2.29+0.3 \times(\mathrm{r} 2=0.58)$, (Figure 5). This means that time of the application of goat manure up to 10 DBT increased the fruit weight of $872 \mathrm{~g}$, diameter of fruit thickness $16.19 \mathrm{~cm}$, and the thickness of edible fruit $2.62 \mathrm{~cm}$. Pattinasarany, (2001) stated that the timing of proper fertilizer application affects the size of flower diameter and flower weight on cabbage plants.
Susanto et al. (2014) revealed that the application of organic materials 30 days before planting gives the best tuber yield of sweet potato. However, this study has not obtained the application time of goat manure to produce good quality melon fruit.

The sweetness of fruit increased with the increase of dosage of $\mathrm{KCl}$ fertilizer (Figure 6). Dosage application of $\mathrm{KCl} 400 \mathrm{~kg} /$ ha showed the highest fruit sweetness level e.i. 8.2 0Brix when compared with other treatments. This indicated that $\mathrm{KCl}$ contributed the content of sugar in melon fruit. This increase in fruit sugar levels is due to increased nutrient uptake of $\mathrm{K}, \mathrm{Ca}$ and $\mathrm{Mg}$ due to the availability of $\mathrm{K}, \mathrm{Ca}$ and $\mathrm{Mg}$ cations in soil solution. Indicator of melon fruit sweetness influenced by fructose content in fruit, the higher the content of fructose the higher the fruit sweetness (Pasaribu, 2014).

Good quality melon fruit characterized by a large fruit size and thick mesocarp size. The highest fruit weight of melon fruit produced from this study was $870 \mathrm{~g}$ which is in the small grade. Environmental factors such as the low rainfall conditions during this study were contributed to the yield. The availability of water affects all aspects of plant growth, which includes physiology, biochemistry, anatomy and morphology (Banyo, 2013).

The incidence of dew diseases on the leaves of melon plants, so that the effect on the leaf area produced is $1604 \mathrm{~cm} 2$ which is relatively small which gives effect to the fruit weight produced is $870 \mathrm{~g}$. when compared with the results of research of Marwanto et al. (2013) which proved the leaf area produced was $4205.75 \mathrm{~cm} 2$ with fruit weight of 1.925 g. From two research above can be concluded that leaf area gives influence to fruit weight. The increase in the area of the leaf will affect the process of photosynthesis, as the solar radiation captured by the plants is higher, resulting in higher photosynthesis resulting in improved fruit weight. Castellanos et al. (2011) found that increase used of organic matter will increase in leaf area of melon plants. Photosynthesis is the ability of plants (through chlorophyll in the leaves) to organize an organic reaction that is the formation of sugar from $\mathrm{CO} 2$ and $\mathrm{H} 2 \mathrm{O}$.

\section{CONCLUSION}

The results of this research concluded that time of application of goat manure 10 DBP effected leaf area to $1619.51 \mathrm{~cm} 2$, fruit fresh weight to $872 \mathrm{~g}$, fruit diameter equal to $16.19 \mathrm{~cm}$ and thickness of edible fruit to $2.61 \mathrm{~cm}$. Potassium doses of $400 \mathrm{~kg}$ / ha was able to increase the melon fruit sweetness by 8.2 0Brix. No interaction of the two treatments affected plant growth and melon yield.

\section{REFERENCES}

Aristya, G.R. and R. D. Perwitasari. Deteksi gen ketahanan terhadap powdery mildew pada melon (Cucumis melo L.) hasil persilangan resiprok indukan ACTION 434 dan PI 371795 . Jurnal. 
Deteksi gen resiprok. Nomor 9.pdf

Banyo, Y. E., N. S. Ai., P. Siahaan., and A. M. Tangapo.2013. Konsentrasi klorofil daun padi pada saat kekurangan air. Jurnal Ilmiah Sains, 13(1):1-8.

Castellanos, M.T., M. J. Cabello, M. del Carmen Cartagena, A. MaríaTarquis, A. Arce, and F. Ribas. 2011. Growth dynamics and yield of melon as influenced by nitrogen fertilizer. Sci. Agric. (Piracicaba, Braz.), 68 (2), p.191-199.

Gomies, L., H. Rehatta, and J. Nandissa. 2012. Pengaruh pupuk organik cair terhadap pertumbuhan dan produksi tanaman kubis bunga (Brassica oleracea var. Botrytis 1.). Agrologia, 1 (1) : 13-20.

Handajaningsih, M., Marwanto, R. Efendi, dan J. Sihombing. 2016. Pertumbuhan dan Hasil Jagung Manis dengan Pemberian Beberapa Jenis, Dosis dan Saat Aplikasi Kompos pada Ultisol. Prosiding Seminar Nasional Inovasi Teknologi Pertanian Modern Mendukung Pembangunan Pertanian Berkelanjutan. Pengkajian Teknologi Spesifik Lokasi Komoditas Tanaman Perkebunan dan Hortikultura. Bengkulu 8 November 2016. Jilid 2. ISBN 978-602-9064-37-7. hal 378 - 383.

Hock, Ong G, G. Subramaniam, and F. Binti Abdullah. 2014. Effect of Trichoderma-Infused Compost on Yield of Chili Plants Int'l Conf. on Advances in Environment, Agriculture \& Medical Sciences (ICAEAM'14) November 1617, 2014 Kuala Lumpur .Malaysia.

Marwanto, M., R. Efendi, M. Chozin, and M. Handajaningsih. 2013. Promoting effect of ethanolic extract of root tuber of Gloriosa superba L. On melon growth and fruit quality. Proceeding on International Symposium on Sustainable Humanosphere. Bengkulu 17-18 September. 2013. Pages $118-122$.

Masnag, A. 2003. Konversi penggunaan lahan kawasan hulu dan dampaknya terhadap kualitas sumberdaya air di kawasan hilir. Makalah Pengantar Falsafah Sains. Program Pasca
Sarjana Institut Pertanian Bogor.

Pasaribu, R. C. 2014. Respon pertumbuhan, hasil dan kualitas tanaman melon (Cucumis melo L.) terhadap dosis pupuk kandang kambing dan dosis pupuk anorganik. Skripsi Program Studi Agroekoteknologi Fakultas Pertanian Universitas Bengkulu.(tidak dipublikasikan).

Pattinasarany, F. R. E. 2001. Penggunaan pupuk subur dengan dosis dan waktu aplikasi yang berbeda pada tanaman kubis bunga. Skripsi Fakultas Pertanian Universitas Patimura Ambon.

Safuan, L.Q dan A. Bahrun. 2012. Pengaruh bahan organik pupuk kalium terhadap pertumbuhan dan produksi tanaman melon (Cucumis melo L.). Jurnal Agroteknos, 2(2) : 69-79.

Saputra, E. A. 2009. Pengaruh waktu aplikasi dan pemberian beberapa kompos azola (Azolla spp.) terhadap pertumbuhan dan produksi tanaman kailan (Brassic oleracea Var. Acephala DC.). Tesis. USU. Sumatra utara medan.

Silvia, M. 2012. Respon pertumbuhan dan hasil tanaman cabe rawit (Capsicum frutescent L.) terhadap pemberian pupuk kandang kotoran kambing pada tanah ultisol. Tesis. IPB. Bogor.

Siswanto, W., Bakti dan Purwadi. 2010. Karakteristik lahan untuk tanaman melon (Cucumis melo L.) dalam kaitannya dengan peningkatan kadar gula. Jurnal Pertanian 12 (2); 125 - 131.

Soedarya, A. 2010. Agribisnis Melon. Pustaka Grafika. Bandung.

Soepardi, G. 1983. Sifat dan Ciri Tanah. Fakultas Pertanian Institut Pertanian.

Susanto E., H. Ninuk and E. S. Nur. 2014. Respon pertumbuhan dan hasil ubi jalar (Lipomoea batatas L.) pada beberapa macam waktu aplikasi Bahan Organik. Jurnal produksi tanaman. 2 (5): 412-418.

Yogev, A. 2009. Suppression mechanism of Fusarium Wilt of melon caused by Fusarium oxysporum f. sp. melonis by compost. Thesis submitted for Doctor of Philosophy Degree. Hebrew University. Israel. 